ーノートー

採血時のエチルアルコール消毒による採取血液へのエチルアルコール混入の有無

中尾隆美 ${ }^{1}$, 津田紀子 ${ }^{1}$, 丸山克之 ${ }^{1 *}$ ，木村貴明 ${ }^{1}$, 太田育夫 ${ }^{* *}$ ，湏口満英 ${ }^{1}$, 石部玩也 ${ }^{1}$ ，新田篤志 ${ }^{2}$, 西岡 裕 $^{2}$, 片木宗弘 ${ }^{2}$, 植嶋利文 ${ }^{1}$

\author{
1近畿大学病院 救命救急センター \\ 干589-8511 大阪府大阪狭山市大野東377-2 \\ 2 大阪府警察本部刑事部科学捜査研究所 \\ 干541-0053 大阪府大阪市中央区本町 1-3-18
}

\title{
Study to establish whether disinfection using ethanol-containing skin antiseptics causes ethanol contamination through blood collection
}

\author{
Takami Nakao ${ }^{1}$, Noriko Tsuda ${ }^{1}$, Katsuyuki Maruyama ${ }^{1}$, Takaaki Kimura ${ }^{1}$, \\ Ikuo Ota ${ }^{1}$, Mitsuhide Hamaguchi ${ }^{1}$, Takuya Ishibe ${ }^{1}$, Atsushi $\mathrm{Nitta}^{2}$, \\ Hiroshi Nishioka ${ }^{2}$, Munehiro Katagi ${ }^{2}$ and Toshifumi Uejima ${ }^{1}$ \\ ${ }^{1}$ Department of Emergency and Critical Care Medicine, Kindai University of Medicine \\ 377-2, Onohigashi, Osakasayama 589-8511, Japan \\ ${ }^{2}$ Forensic Science Laboratory, Osaka Prefectural Police Head Quarters \\ 1-3-18, Hommachi, Chuo-ku, Osaka 541-0053, Japan \\ (Received 17 June 2019; accepted 9 August 2019; \\ Published online 23 October 2019 in J-STAGE DOI: 10.3408/jafst.767)
}

This study is aimed to establish whether the skin preparation using ethanol (EA)-containing skin antiseptics causes EA contamination through blood collection. Venous blood was collected from 40 healthy volunteers according to the national guidelines for blood sampling, with four sequential procedures as follows: 1) collecting immediately (within $5 \mathrm{~s}$ ) after cleaning the skin with each packaging type of EA-containing pad, 2) collecting 1 minute after cleaning the skin with each packaging type of EA-containing pad, 3) collecting immediately (within $5 \mathrm{~s}$ ) after cleaning the skin with a traditional cleaning method (with a thoroughly EA-impregnated pad, and 4) collecting 1 minute after cleaning the skin with a traditional cleaning method. Each sequential procedure was performed with and without the EA-con-

\footnotetext{
* 現所属 : ベルランド総合病院 総合内科

干599-8247 大阪府堺市中区東山500-3

General Internal Medicine, Bellland General Hospital

500-3, Higashiyama, Naka-ku, Sakai 599-8247, Japan

** 現所属 : 社会医療法人三和会 永山病院 救急科

干590-0406 大阪府泉南郡熊取町大久保東 1-1-10

Department of Emergency Medicine, Nagayama Hospital

1-1-10, Ookubohigashi, Kumatori-cho, Sennan-gun 590-0406, Japan
} 
taining pad used for skin cleaning pressed against the puncture site on their right and left arms at the time the needle was withdrawn, respectively. The collected specimens were subjected to determination of EA by using head space gas chromatographymass spectrometry.

In every 80 blood specimen obtained from 40 participants, EA was undetectable $(<0.001 \mathrm{mg} / \mathrm{mL})$. This study demonstrates that disinfection using ethanol-containing skin antiseptics is unlikely to cause ethanol contamination through blood collection regardless of skin preparation technique according to the guidelines for blood sampling.

Key words: BAC testing, Skin antiseptic, Contamination of ethyl alcohol

\section{緒 言}

エチルアルコール（EA）は，古くから嗜好品で ある “打酒”として我々の日常生活に深くかかわっ てきた．EAは，ヒトに対して多幸感を与え人間関 係を良好に深めるなどの効用がある。しかしその一 方で，EA は理性・自制心の低下を生じさせること から，飲酒に係る暴行や傷害あるいは殺人などの凶 悪犯罪の引き金となるほか，飲酒運転による悲惨な 交通事故や過量摂取による急性中毒事故も頻繁に発 生し, EA は事件・事故を誘発する薬物として法化 学分野に抢ける最も重要な薬物の一つとなってきて いる.

中でも飲酒運転は，人の生命にかかわる悲惨な交 通事故に発展する可能性が高いことから, 道路交通 法あるいは自動車運転死傷処罰法などにより厳しく 処罰される。しかしながら，このような法律による 厳罰化が進められているにもかかわらず，飲酒運転 による交通事故や不祥事案は枚挙の暇がないほどで あり，大きな社会問題となっている.

$\mathrm{EA}$ の作用は，中枢神経系の抑制作用であり，そ の影響の程度には個人差があるものの，一般的には 血液中濃度に比例すると考えられて抢り，血液中 EA 濃度と酩酊との関係も明らかとなっている11). すなわち，低レベルの血中濃度では，抑制系神経に 対する抑制効果のため興奮が助長される（アルコー ル作用の発揚期）が，血中濃度の上昇とともに運動 や知覚中枢にも抑制が掛かり, 運動の反射時間の延 長や刺激への無反応を生じ（アルコール作用の酩酊 期)，さらに血中濃度が上昇すると脳幹抑制により
死に至る。このように血液中 EA 濃度と酩酊の度合 いとは密接な関係があることから，法的責任能力を 判断するうえで，血液中 EA 濃度測定が必要不可欠 となっている，特に我が国の道路交通法では，厳格 な血液中 $\mathrm{EA}$ 濃度規定を設定（EA 濃度 $0.3 \mathrm{mg} / \mathrm{mL}$ 以上を酒気帯び運転）し，交通事故防止対策の一翼 を担ってきた。

血液中 EA 濃度の測定では, 低濃度領域での正確 な定量が必要とされることから，ガスクロマトグラ フィー（GC）やガスクロマトグラフィー質量分析 （GC/MS）による高感度で精度の高い濃度測定法 が汎用されているが，それとともに採血段階での EAのコンタミネーションには細心の注意を払う必 要がある。そのため, 検知拒否などに伴う強制採血 に際しては, 可能な限り塩化ベンザルコニウムやク ロルヘキシジングルコン酸塩あるいはイソプロピル アルコールなどの EA を含有しない消毒液での皮膚 消毒を採血する医療従事者に依頼している。さら に，我が国の標準採血法ガイドラインでも「血中ア ルコール濃度を測定する場合はアルコールを含まな い消毒薬を用いる」と提示されている. しかし，通 常の採血法とは異なることから採血に時間と手間を 要することが多く，採血ができない事態も散見され るほか，不本意ながら EA での皮膚消毒後に採血さ れる事案も発生している.

一方，交通事故などに伴う受傷者は，治療のため 病院に搬送されるが，飲酒や薬物使用など事件性が 疑われる場合，治療の際に採取した血液を警察に提 供することをしばしば求められる。しかし，特に救 命救急センターなど生命にかかわるような交通事故 
の受傷者が搬送されてくることが多い施設では，一 刻を争う救命処置が必要とされるため，飲酒の有無 が分からない状況で，「今後，血中アルコール濃度 を測定する.」という警察の要請に応じた血液採取 法により受傷者の血液を採取することはほとんど不 可能に近いのが現状である.

採血時の皮膚消毒は，現在ほとんどの施設では， 感染防止の観点などから EA 含有個包装製品を使用 している.しかし個包装が定着する以前は，各施設 で“アルコール綿”を作成し，その “アルコール綿” を絞ったものを用いて皮膚消毒を行い採血をしてい た。そのため，十分に絞られていなかった可能性も あり，採血操作により採取血液への EA の混入が否 定できないことから，EA不使用での血液の取り直 しをしばしば求められた。しかし，再採血を行った 血液資料から得られる血液中 $\mathrm{EA}$ 濃度は, 事故当時 の受傷者の血液中 EA 濃度を反映するものではな く, 事故後の時間経過に比例して低くなっていくこ とが予想され，EAが検出されないこともしばしば 見られる。さらに，再採血した血液から $\mathrm{EA}$ が検出 された場合でも，事故当時の受傷者の血液中 EA 濃 度を推定するため, Widmark 法による逆算がしば しば行われているが，治療に伴う補液や，代謝によ る相当大きな個人差を考慮に入れる必要がある.

$\mathrm{EA}$ を用いた皮膚消毒による採取血液への EAの コンタミネーションの有無に関しては，これまでい くつかの実験例が報告され2-8)，国内ではその可能 性を示唆する報告 ${ }^{2}$ がある一方で, 海外ではコンタ ミネーションを否定する報告7,8) もある。これは， 国内外での消毒用脱脂綿の EA 含有量や皮膚消毒後 の時間, あるいは採血方法など血液採取の条件に差 異があり，それらが影響していることが予想され る.さらに近年我が国では，EA 消毒には EA 含有 量の少ない個包装製品の利用が定着していることか ら，EAによる皮膚消毒の影響が無いことが予想さ れる。

そこで本研究では，現在我が国で一般的に実施さ れている EAによる皮膚消毒後に血液を採取する方 法により採取血液へのEAのコンタミネーションの 有無を検証した。

なお本研究は, 近畿大学医学部倫理審査委員会の
承認（受付番号 : 29-019）を得たうえで実施した。

\section{材料および方法}

\section{1. 試薬}

注射器はテルモシリンジ $5 \mathrm{~mL}$ (SS-05SZ), 注射 針はテルモ注射針 $23 \mathrm{G} \times 11 / 4 （ \mathrm{NN}-2332 \mathrm{R})$ を用い た. EA は富士フイルム和光純薬製精密分析用試 薬, 消毒用 EA は健栄製薬社製消毒用エタノール, 個包装 EA 含浸綿は白十字社製ワンショットプラス ${ }^{\circledR} \mathrm{P}$ EL-2（76.9〜81.4 Vol\%の EA を $1.6 \mathrm{~mL}$ 含有） を使用した．2-メチル-1-プロパノールは富士フィ ルム和光純薬製特級試薬を内部標準として使用し た。EAを含有しないブランク血液には、コージン バイオ製正常ヒト全血液（抗凝固剂入り）を使用し た。

$\mathrm{EA}$ 標準溶液は, $100 \mu \mathrm{g} / \mathrm{mL}$ 水溶液を調製し, 適 時ブランク血液により希釈して使用した.

\section{2. インフォームド・コンセント}

20 歳以上の健康なボランティア男女 40 名（男性 25 名, 女性15名）に, 本研究の主旨と内容について文 書を用いて詳しく説明し, 理解・同意を得た.

\section{3. 採血前問診および呼気中 $\mathbf{E A}$ 濃度測定}

被験者40名の年齢, 性別, 採血時屯での飲酒の有 無と飲酒量および現在の服用薬歴について問診を実 施した. 前日に飲酒歴のある被験者については, 採 血に先立ち呼気アルコールチェッカー（アイリス オーヤマ社製 ALC-D1）を用いて呼気中 EA 濃度 測定を実施し，EAが検出されないことを確認し た。

\section{4. 採血法}

被験者 40 名を各 10 名ずつ以下の 4 群に分類し, さ らに Fig. 1 に示すように各被験者について抜針の 際に針入部を EA 含有綿で押さえる場合（右腕）と 押さえない場合（左腕）の2通りについて我が国の 標準採血法ガイドライン9)に準じて血液各 $2 \mathrm{~mL}$ を 採取した。

（1) 個包装 EA 含有綿で消毒後ただちに採血する 群

(2) 個包装 EA 含有綿で消毒 1 分後に採血する群

(3) 従来法（消毒用 EA を十分に湿らせた脱脂綿 を使用する方法）で消毒後ただちに採血する 


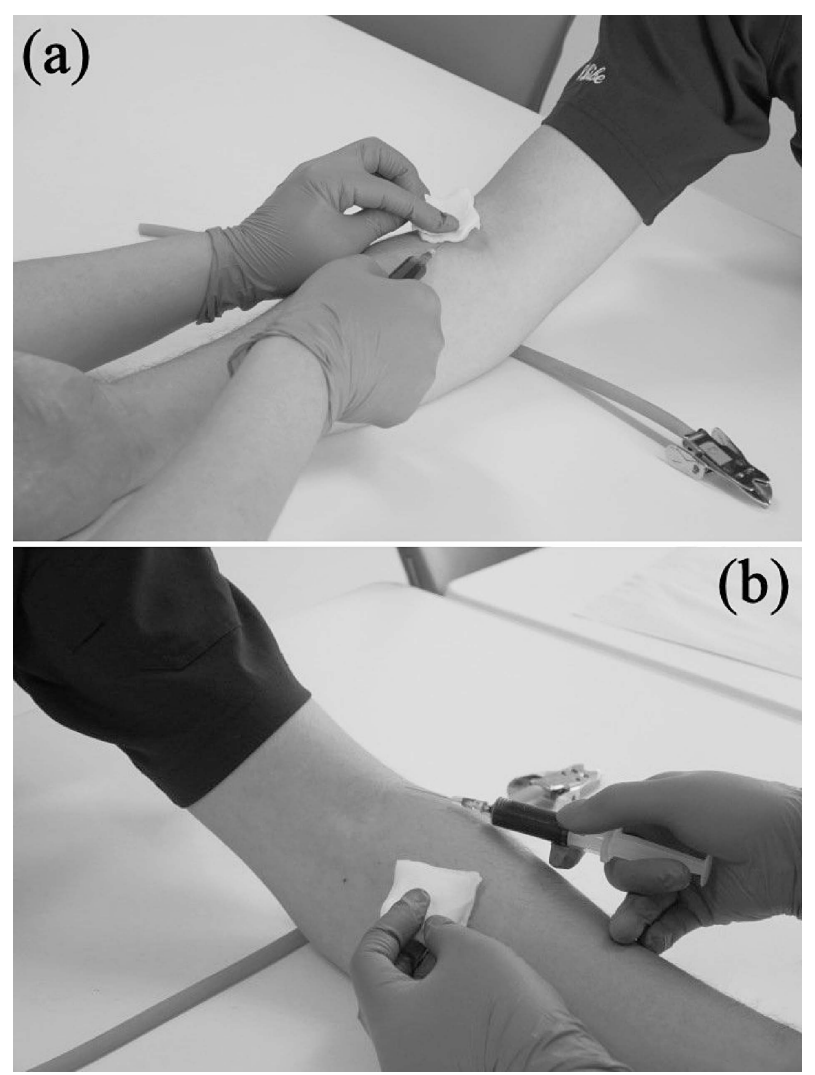

Fig. 1 Withdrawal of the needle:

(a) with the EA-containing pad pressed against the puncture site.

(b) without the EA-containing pad.

群

(4) 従来法で消毒 1 分後に採血する群

採血に際しては，公正を期するため，採血者には 実験の趣旨は伝えず，また手技の偏りを防ぐ為に， 計15名(医師および検査技師)により採血を行った。

採取した血液は，EDTA 含有採血管（BDバキュ テイナ採血管 REF 368843）に入れて冷凍保存した 後, ガスクロマトグラフィー質量分析 (GC/MS) により血中 EA 濃度を測定した。

\section{5. 血液中 $\mathbf{E A}$ 分析法}

$20 \mathrm{~mL}$ 容ガラス製バイアル（ジーエルサイエン ス社製）に試料 $0.5 \mathrm{~mL}$ と内部標準 $(0.25 \mathrm{mg} / \mathrm{mL}$ 2-メチル-1-プロパノール水溶液） $0.5 \mathrm{~mL}$ を入れ， セプタム付クリンプキャップ（ジーエルサイエンス 社製）で密栓し，ヘッドスペースガスクロマトグラ フィー質量分析（HS-GC/MS）により EAの定性
および定量を行った。

なお，分析は各検体につき， 3 回実施した.

6. 装置および測定条件

1）へッドスペースオートサンプラー分析条件

装置：PerkinElmer 社製 TurboMatrix40型ヘッド スペースオートサンプラー

オーブン温度 : $60^{\circ} \mathrm{C}$

保温時間 : $15 \mathrm{~min}$

ヘッドスペースモード：コンスタント

注入時間 : $0.05 \mathrm{~min}$

ニードル温度 : $100^{\circ} \mathrm{C}$

トランスファ温度 : $150^{\circ} \mathrm{C}$

加圧時間 : $1 \mathrm{~min}$

引き上げ時間 : $0 \mathrm{~min}$

$\mathrm{HS}$ キャリアガス圧力 : $70 \mathrm{kPa}$

2) $\mathrm{GC} / \mathrm{MS}$ 分析条件

装置 : 島津製作所製 GCMS-QP2010 Plus 型ガス クロマトグラフ質量分析計

カラム : RESTEK 社製 Rtx-BAC2 (0.32 mm i.d. $\times 30 \mathrm{~m}$ ，膜厚 $1.2 \mu \mathrm{m})$

カラム温度 : $40^{\circ} \mathrm{C}(5 \mathrm{~min})-200^{\circ} \mathrm{C}(1 \mathrm{~min}), 40^{\circ} \mathrm{C} /$ $\min$

気化室温度 : $200^{\circ} \mathrm{C}$

インターフェイス温度 : $230^{\circ} \mathrm{C}$

イオン源温度 : $200^{\circ} \mathrm{C}$

キャリアガス：ヘリウム

制御モード : 線速度 $(60.0 \mathrm{~cm} / \mathrm{sec})$

イオン化法 : 電子イオン化 $(\mathrm{EI})$

測定モード：scan モード

\section{実験結果}

1. HS-GC/MS による EA の定性および定量

1) validation

通常の血液中 EA の鑑定では，GC/MS の scan モードによる定性分析と定量分析を行うことから， 鑑定検査に及ぼす影響を検証する目的に鑑久て， scan モードに拈けるEAの HS-GC/MS での validationを実施した。

$\mathrm{EA}$ 標準水溶液をブランク血液を用いて希釈し, $0.03,0.1,0.3,1.0,2.0 \mathrm{mg} / \mathrm{mL}$ の濃度に調製した. これら試料について HS-GC/MS による血液中 EA 
の検量線を作成したところ，0.03-2.0 mg/mL の範 囲で良好な直線性（ $\mathrm{y}=0.511 \mathrm{x}+0.00415, \mathrm{r}^{2}=0.999 ）$ を示した。また， $0.03,1.0,2.0 \mathrm{mg} / \mathrm{mL}$ の各濃度に おける日内に打ける精度（precision）打よび確度 (accuracy) は，変動が各々 0.6 おび $2.5 \%, 0.2$ お よび $0.5 \% ， 0.6$ おび $0.2 \%$ であった。また， $1.0 \mathrm{mg}$ $/ \mathrm{mL}$ の濃度における異なる 6 日間の測定精度は変 動が $1.3 \%$ であった。さらにscanモードにおける $m / z 31$ の抽出イオンクロマトグラムでの検出限界 （S/N>3）は0.001 mg/mLであった.

道路交通法における酒気帯び運転の血液中 EA 濃 度の基準值は $0.3 \mathrm{mg} / \mathrm{mL}$ であるが，保存血液から の腐敗による $\mathrm{EA} の$ 生成の影響も報告されているこ とから，当研究所では血液資料中 EA の定性および 定量下限を $0.03 \mathrm{mg} / \mathrm{mL}$ に設定している。本法は, EA 消毒によるEA コンタミネーションの EA 鑑定 検査に及ぼす影響を検証するには十分な精度と感度 を有していると考えられた。

\section{2）実検体の分析}

前項の結果に基づき40名分合計 80 検体の採取血液 について, scan モードによる HS-GC/MS を行っ た。その結果，Table 1 に示すように，80検体いず れからも EA は検出されなかった。

な抢，Fig. 2 に，実検体の任意の 1 検体および $\mathrm{EA}$ 濃度が $0.001 \mathrm{mg} / \mathrm{mL}$ になるように EA を添加し たブランク血液の分析結果を示す.
2. EA 皮膚消毒法および抜針法の差異が EA コン タミネーションに及ばす影響の検討

1） EA 皮膚消毒法の差異が及ぼす影響

我が国の標準採血法ガイドラインでは，「穿刺部 位の消毒を行い，消毒液が乾燥するまで待つ」こと が推奨されている。しかし，血液採取時に行われる 皮膚消毒の後, 穿刺部位が完全に乾燥しているか否 かの確認は困難であり，消毒から採血までの時間も 採血者により異なる．特に一刻を争う救命救急の現 場では，乾燥まで十分に待てないことも多い。その ため，血液採取時に行われる皮膚消毒に EA が使用 された場合，消毒から採血までの時間によっては $\mathrm{EA}$ が採血部分の皮膚表面に残存し，採取血液への $\mathrm{EA}$ コンタミネーションの原因となる可能性があ る．そこで皮膚消毒後ただちに採血する場合（1） (3)群）および消毒後 1 分経過した後に採血する場合 (2)，(4)群）の 2 通りについて EA コンタミネーシ ョンの有無を検証した。その結果，Table 1 に示す ように，いずれの方法を用いても EA は検出され ず，コンタミネーションは認められなかった。

さらに，皮膚消毒を行う際に使用する綿に含有す る EA 含有量によっても，採取血液への EA コンタ ミネーションを引き起こす可能性がある。 そこで, 現在普及し汎用されている個包装 EA 含有綿（1), (2)群) と，従来用いられていた消毒用 EA で十分に 湿らせた脱脂綿を使用する方法（3), (4)群) の2 種 類の消毒法により $\mathrm{EA}$ 皮膚消毒を行い，採取血液へ の EA コンタミネーションの有無を検証した。その

Table 1 Results from HS-GC/MS of 80 blood specimens.

\begin{tabular}{|c|c|c|c|c|c|}
\hline Group & Alcohol swab & $\begin{array}{l}\text { Waiting } \\
\text { time }\end{array}$ & $\begin{array}{l}\text { Method of } \\
\text { withdrawal }\end{array}$ & $\begin{array}{l}\text { Number of } \\
\text { specimens }\end{array}$ & $\begin{array}{l}\text { Concentration } \\
\text { of detected EA }\end{array}$ \\
\hline (1)-1 & \multirow{2}{*}{ Each packaging type } & \multirow{2}{*}{ Within $5 \mathrm{~s}$} & With the EA-pad & 10 & - a) \\
\hline (1) -2 & & & Without the EA-pad & 10 & - a) \\
\hline (2) -1 & \multirow{2}{*}{ Each packaging type } & \multirow{2}{*}{1 minute } & With the EA-pad & 10 & -a) \\
\hline (2) -2 & & & Without the EA-pad & 10 & - a) \\
\hline (3) -1 & \multirow{2}{*}{$\begin{array}{c}\text { Thoroughly } \\
\text { EA-impregnated pad }\end{array}$} & \multirow{2}{*}{ Within $5 \mathrm{~s}$} & With the EA-pad & 10 & -a) \\
\hline (3) -2 & & & Without the EA-pad & 10 & - a) \\
\hline (4) -1 & \multirow{2}{*}{$\begin{array}{c}\text { Thoroughly } \\
\text { EA-impregnated pad }\end{array}$} & \multirow{2}{*}{1 minute } & With the EA-pad & 10 & -a) \\
\hline (4) -2 & & & Without the EA-pad & 10 & - a) \\
\hline
\end{tabular}

a) EA was not detected from all specimens. 

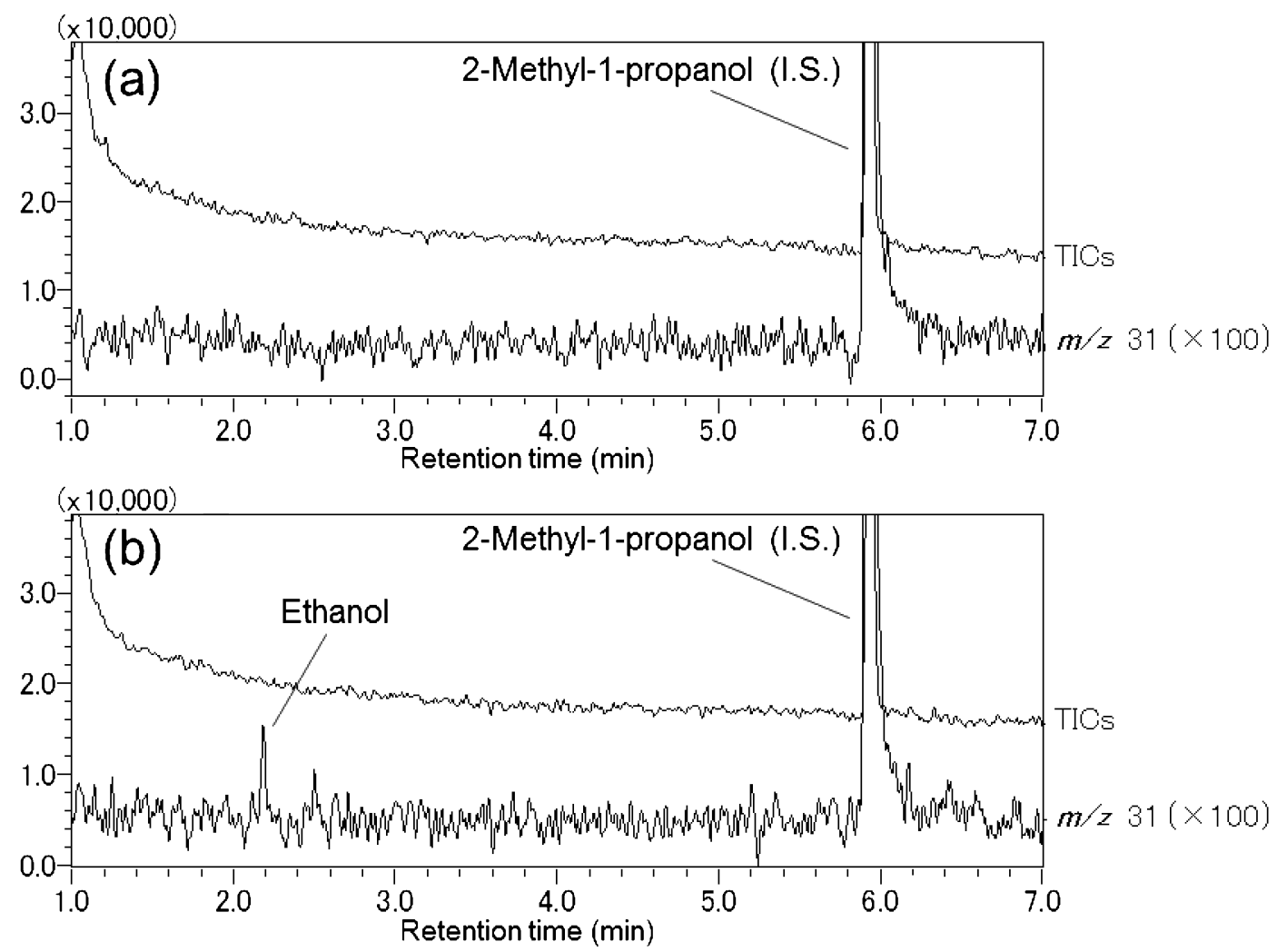

Fig. 2 Total ion current chromatograms (TICs) and extracted ion chromatograms (EICs) obtained from (a) one of 80 blood specimens (EA was not detected) and (b) the blank blood specimen spiked with EA (concentration: $0.001 \mathrm{mg} / \mathrm{mL}$ ).

結果，Table 1 に示すように，いずれの EA 含有綿 を用いても EA は検出されず，コンタミネーション は認められなかった。

\section{2）抜針法の差異が及ぼす影響}

前記ガイドラインでは，採血後抜針する際には 「穿刺部位に消毒綿またはガーゼを軽くあてた状態 で針を抜き，圧迫する」ことが推奖されていること から，EA 含有綿で皮膚消毒を行った際には，抜針 時に針入部を皮膚消毒した EA 含有綿で押さえるこ とがほとんどの場合行われている。したがって抜針 時に注射器で $\mathrm{EA}$ を吸引してしまうことによる EA コンタミネーションの可能性が考えられる。そこ で，抜針の際に針入部を皮膚消毒に用いた EA 含有 綿で押さえる場合（(1)-1，(2)-1，(3)-1，(4)-1 群） と押さえない場合（(1)-2, (2)-2, (3)-2, (4)-2 群) の 2 通りについて採取血液への EA コンタミネーシ
ヨンの有無を検証した。そ結果，Table 1 に示す ように，いずれの抜針法を用いても EA は検出され ず，コンタミネーションは認められなかった。

\section{考 察}

血液中 EA 濃度測定に及ぼす EA 皮膚消毒の影響 については，様々な条件のもとで国内外で検証がな されてきた．我が国では Higuchi らが EA 綿で消毒 し， 1 分程度乾燥後に採血した場合はほとんど混入 がみられないが，針が EA 綿に触れていた場合は EAの混入が起こり, 混入量は最大 $0.12 \mathrm{mg} / \mathrm{mL}$, 三倍量の EA を用いた場合は最大 $0.19 \mathrm{mg} / \mathrm{mL}$, さ らに指がピストンに触れているとかなりの例で EA が混入し，混入量は最大 $9.6 \mathrm{mg} / \mathrm{mL}$ であったと報 告している2)。海外では Müller と Hundt は，真空 採血管での採血時に針が EA 綿に触れていた場合, EAの混入量は $0.02 \sim 34 \mathrm{mg} / \mathrm{mL}$ であったと報告し 
ている3). Winek と Eastlyは，EA 綿で消毒した場 合, EA の混入量は平均 $0.026 \mathrm{mg} / \mathrm{mL}$ で，採血者が 標準的な方法に従った場合の混入量は平均 $0.006 \mathrm{mg}$ $/ \mathrm{mL}$ であったが，採血者が意図的に採血部を EA で相当に湿らせた場合には平均 $0.89 \mathrm{mg} / \mathrm{mL}$ の混入 があったと報告している4). Peek らは，EA 綿で消 毒し，乾燥後に採血した場合，EAの混入量は $0.070 \pm 0.067 \mathrm{mg} / \mathrm{mL}$ であったと報告している5).

さらに, Yigit とArslanは, 消毒に EA とポピドン ヨードを用いて採血した救急患者の血中 EA 濃度が $4.53 \mathrm{mg} / \mathrm{mL}$ と異常に高い值を記録したため, 消毒 にEAを使用せずに再採血を実施したところ EA 濃 度は $0.003 \mathrm{mg} / \mathrm{mL}$ に減少した事例を報告してお り6)，これらの報告では，EA 皮膚消毒が，血液採 取の際のコンタミネーションの原因となり，血中 EA 濃度に影響を及ぼしているとされている。

一方，我が国の報告例はないものの，海外では Malingré らの報告7) や Lippi らの報告8)によれば, コンタミネーションは認められず，理想的な EA 皮 膚消毒であれば血中 EA 濃度に影響を及ぼすことは ないと結論付けている.

このように，EA 皮膚消毒によるEAのコンタミ ネーションについては正反対の報告がなされてい る.しかし, 消毒綿の種類や EA の湿らせ方, 皮膚 消毒から採血までの時間，あるいは抜針の際の消毒 綿の当て方など，その時代や国によって，さらには 個人差もあることから，血液採取の際の条件が一定 ではないことが，結果の食い違いの大きな要因とな っていることが考えられる. 特にEAで濡れたまま で抜針するなどの操作により針と消毒綿が触れる， あるいは抜針の際に指がピストンに触れているとい った抜針時の操作法によってはかなりの確率で EA のコンタミネーションを引き起こすことが報告され ている.

いずれにしても，採血の際の条件によっては EA 皮膚消毒が血液採取の際のコンタミネーションの原 因となる可能性が否定できないことは事実である.

特に Higuchi らの報告は，これまで我が国における 唯一の検証結果として引用され，EA 皮膚消毒を行 った際の採血資料が血中アルコール鑑定における証 拠価值を否定する大きな根拠とされてきた。しかし
ながら当時の消毒法は, 現在のそれとはかなり異な る点がある. EA 皮膚消毒に際しては, 前出の標準 採血法ガイドラインに「消毒効果の確実性, 清潔度 の観点からみて, 個別包装のものが望をしい.」と の記載もあることから, 現在では個包装 EA 含有綿 の使用が一般化しているが，個包装 EA 含有綿の使 用が定着する以前には，各施設で消毒用 EA により 十分に湿らせた脱脂綿を作成し, それを用いて消毒 を行い，採血後抜針の際には脱脂綿を皮膚に当てて 行う方法が一般的であった。このことから，

Higuchi らの報告に見られたEAのコンタミネーシ ヨンは，十分に絞られていなかった脱脂綿に残った エタノールを採血の際に吸引していたことが主な要 因と考えられる.

今回の実験から，個包装 EA 含有綿が普及してい る現在の状況では，EA 皮膚消毒を行った場合で も, 我が国の標準採血法ガイドラインに準じた採血 方法では, 採取した血液中にエタノールが混入する ことはないと考えられた。

\section{結 語}

採血時の EA 皮膚消毒が，採取血液への EA コン タミネーションを引き起こすか否か検証を行った。

2 種類の EA 含有綿を使用し, さらに皮膚消毒後採 血までの時間を変えることで EA 皮膚消毒法の影響 を検討した。さらに抜針法の影響について，抜針時 に EA 含有綿を使用する場合と使用しない場合の差 異についても同様に検討した. その結果，いずれの 方法を用いても EAのコンタミネーションは認めら れなかった。このことから，我が国の標準採血法ガ イドラインに準じた採血方法では，EA 皮膚消毒を 行った場合でも，採取した血液中にエタノールが混 入することはないと考えられた.

ただし，飲酒に係る犯罪では，公判において血液 中 $\mathrm{EA}$ 濃度が大きな争点になることも多い。その 際，血液採取時に EA が使用されている場合には， 消毒に使用した EA のコンタミネーションの可能性 を言及されることは想像に難くない.今回の検証実 験に基づけば，コンタミネーションの可能性は否定 することができるが，消毒に EA を使用しなければ コンタミネーションの可能性は全くないわけであ 
り，公判対策上からも EAによる皮膚消毒を回避す ることが望ましいのは言うまでもない。したがっ て, 今後も血液採取に抢ける注意点として, 標準採 血法ガイドラインにも示されているように, EAに よる皮膚消毒を回避する採血法を推奨していくこと が望ましい.

しかしながら，受傷者の治療に一刻を争うような 救急の現場での, 血中アルコール測定目的の血液採 取であっても EA 消毒の回避を考慮する余裕のない 場合, あるいは $\mathrm{EA}$ 皮膚消毒後の採取血液しか入手 できず，経過時間の問題から再採血も不可能である 場合でも，これまでは EA 消毒後の採血であれば $\mathrm{EA}$ 消毒に伴う EA のコンタミネーションの可能性 があるという理由から，証拠価值のない資料として EA 濃度測定に付されることがなかったが，本検証 実験から EA 消毒による EA のコンタミネーション が認められなかったことで, 抜針法などの採血操作 の詳細を確認すれば，これまで証拠価值が否定され てきた資料の鑑定も可能になるものと期待される.

\section{文献}

1) 日本薬学会 (編), 薬毒物試験法と注解 2017. pp. 68, 東京化学同人, 東京, 2017.

2) Higuchi A., Kurihara R., Yoshimoto T., Sano T., Katsumata K., Ishii A. and Katsumata Y., Problems in blood alcohol testing of severely injured drivers brought to emergency departments in Japan. Leg. Med. (Tokyo), 7, 299-305, 2005.
3) Müller F. O. and Hundt H. K. L., Ethyl alcohol: contamination of blood specimens. S. Afr. Med. J., 50, 91, 1976.

4) Winek C. L. and Eastly T., Factors affecting contamination of blood samples for ethanol determinations. Legal Medicine Annual: 1976. pp. 147162, Appleton \& Lange, New York, 1977.

5) Peek G. L., Marsh A., Keating J., Ward R. J. and Peters T. J., The effects of swabbing the skin on apparent blood ethanol concentration. Alcohol Alcohol, 25, 639-640, 1990.

6) Yigit O. and Arslan S., Swabbing skin with alcohol could change the blood alcohol level significantly. J. Emerg. Med., 43, 718-719, 2012.

7) Malingré M., Ververs T., Bos S., van Kesteren C. and van Rijn H., Alcohol swabs and venipuncture in a routine hospital setting: no effect on blood ethanol measurement. Ther. Drug Monit., 27, 403-404, 2005.

8) Lippi G., Simundic A. M., Musile G., Danese E., Salvagno G. and Tagliaro F., The alcohol used for cleansing the venipuncture site does not jeopardize blood and plasma alcohol measurement with head-space gas chromatography and enzymatic assay. Biochem. Med. (Zagreb), 27, 398-403, 2017.

9）JCCLS GP4-A3, 標準採血法ガイドライン, 2018. 